Animal Health Research Institute, Assiut Laberatory.

\title{
LEVELS OF SOME HEAVY METALS IN MEAT AND ORGANS OF CATTLE AND THEIR HAZARD EFFECTS ON PUBLIC HEALTH IN ASSIUT GOVERNORATE
}

\author{
(With One Table)
}

\author{
By \\ MANAL M. SAYED and DOHA Y. AHMED*
}

*Dept. of Forensic Medicine and Toxicology, Fac. Vet. Med., Assiut University 71526, Assiut, Egypt.

(Received at 16/8/2009)

مستوى بعض المعادن الثقيلة في لحوم وأعضاء الأبقار وأثارها على الصحة العامة بمحافظة أسيوط. منال محمد سبا ، ضحى بيبي أحمد

هدفت هذه الدراسة إلى قياس مستوى بعض العناصر الثقيلة مثل عنصر الكادميوم و عنصر

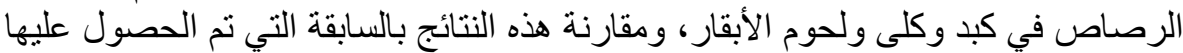

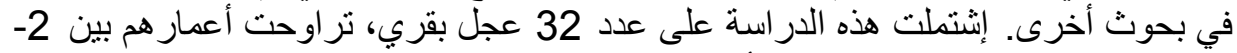

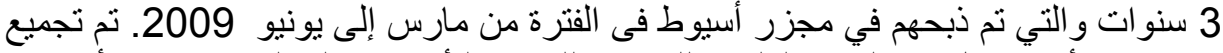

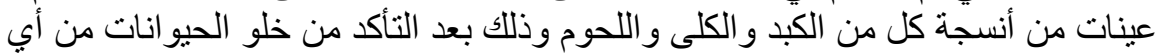

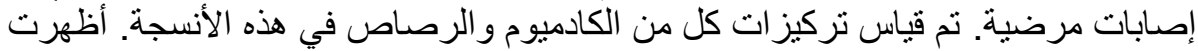

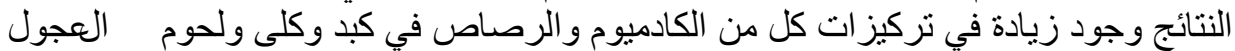

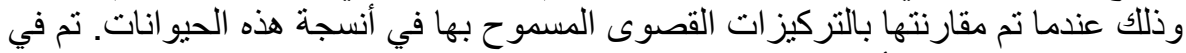
هذه الدر اسة مناقتة التأثير السام لزيادة هذه العناصر الثقيلة على صحة الإنسان.

\section{SUMMERY}

Cadmium and lead concentrations in the liver, kidney and muscle from 32 male cattle (2-3 years old) slaughtered in Assiut slaughterhouse, from March to Jun 2009, were quantified. Analysis was performed by Atomic Absorption Spectrophotometry. The mean cadmium concentrations were $0.52 \pm 0.03 ; 0.58 \pm 0.03$ and $0.40 \pm 0.2 \mathrm{ppm}$ in the liver, kidney and muscles respectively. The mean lead concentrations in the liver, kidney and muscles of the examined samples were $1.20 \pm 0.17 ; 3.74 \pm 0.27$ and $1.01 \pm 0.28 \mathrm{ppm}$ respectively. Cadmium and lead concentrations in the 
estimated tissues of the examined cattle exceeded the acceptable maximum concentrations that have been adopted by many countries. The adverse health effect due to consumption of this meat, liver and kidneys were discussed.

Key words: Cadmium, lead, muscle, liver, kidney

\section{INTRODUCTION}

Heavy metals are invaluable and unavoidable components of our environment. They are in varying quantities throughout the geosphere and are being cycled continuously through different components of the ecosphere. The amounts of different heavy metals in ambient atmosphere have been increasing with advances of human civilization and are likely to increase further with increasing exploitation of geological resources, such as mining and fossil fuel development (Hammond and Aronson, 1964; Chow, 1970 and Fleischer et al., 1974). Swarup et al. (1997) recorded that farm animals are often exposed to toxic heavy metals including cadmium and lead which are disseminated into environment from number of sources. Animal may gain excess cadmium and lead from water soil and vegetation contaminated from industrial and automobile emission.

Animal tissues like liver, kidney and muscle retention would represent the major source of cadmium and lead to the human diet (Johnson et al., 1981). WHO (2007) also reported that, food is the main source of cadmium exposure in the general population, while ingestion of lead through food and water is the major exposure pathway for lead in adults. The continuous consumption of feed stuffs contaminated with heavy metals exceeding the safe permissible limits may result in a serious health problem through progressive irreversible accumulation in human body (Goyer, 1986).

Recent data indicate that adverse health effects of cadmium may occur at lower exposure levels than previously anticipated, primarily in the form of kidney damage but possibly also bone effects and fractures as well as carcinogenic effect (Lars, 2003). Lead is a well-known neurotoxin and cause impairment of neurodevelopment in children (WHO, 2007). It is also potentially carcinogenic (Steenland and Boffetta, 2000).

The aim of this study was to determine the levels of cadmium and lead in cattle liver, kidney and meat in Assiut, Egypt and to compare 
them with concentrations in cattle elsewhere and to the maximum acceptable levels.

\section{MATERIALS and METHODS}

A total of 32 male cattle (2-3 years old) were subjected to study. These animals were slaughtered from March to Jun 2009 in Assuit slaughterhouse belongs to Assiut governorate. Samples of at least $5 \mathrm{~g}$. were obtained from: the liver, kidney and skeletal muscle (psous major muscle). All samples were packed in clean, labeled plastic bags and then kept in deep freeze $\left(-20^{\circ} \mathrm{C}\right)$ for chemical analysis.

\section{Analytical methods}

Tissue specimens were digested according to Koirtyohann et al. (1982) using nitric acid. All chemicals used were of analytical-reagent grade and the highest purity available. Double distilled deionized water, HPLC-grade, were used throughout. Glass vessels were cleaned by soaking in acidified solutions of nitric acid and rinsed several times with high-purity deionized water. Nitric acid (approx. 65\%, Merck) was used. Metal levels were calculated on the basis of similarly prepared Merck standards. Lead and cadmium concentrations were determined in digested samples using Atomic Absorption Spectrophotometry (Atomic absorption 906, GBC, Australia). The analysis was done at Dept. of 99Soil, Faculty of Agriculture, Assiut University.

\section{Statistical analysis}

All statistical analyses were performed using SPSS statistical software (SPSS for Windows, Version 14.0, CA, and USA). Data were subjected to descriptive analysis, and then tissue concentrations of cadmium and lead were compared using Least Significant Difference (LSD).

\section{RESULTS}

Estimation of cadmium in liver, kidney and muscle was presented in table 1 . Levels of cadmium in the liver kidney and muscles of investigated cattle were $0.52 \pm 0.03,0.58 \pm 0.03$ and $0.40 \pm 0.2 \mathrm{ppm}$ respectively. No significant changes were recorded in cadmium concentration between liver and muscle and between liver and kidney. Cadmium concentration in kidney was higher than in muscle.

Estimation of lead level in liver, kidney and muscle was presented in table 1 . The levels of lead in the liver, kidney and muscles 
of examined cattle were $1.20 \pm 0.17,3.74 \pm 0.27$ and $1.01 \pm 0.28 \mathrm{ppm}$ respectively. Lead concentration in kidney tissues was higher than in muscle and liver. No significant change in lead concentration between muscle and liver.

Table 1: Values of cadmium and lead concentrations (ppm) in tissues

\begin{tabular}{|l|c|c|c|}
\hline & $\begin{array}{c}\text { Liver } \\
(\text { No.=32) }\end{array}$ & $\begin{array}{c}\text { Kidney } \\
(\text { No.=32) }\end{array}$ & $\begin{array}{c}\text { Muscle } \\
(\text { No.=32) }\end{array}$ \\
\hline Cadmium (ppm) & $0.52 \pm 0.03^{\mathrm{a}}$ & $0.58 \pm 0.03^{\mathrm{ab}}$ & $0.40 \pm 0.02^{\mathrm{ac}}$ \\
\hline Lead (ppm) & $1.20 \pm 0.17^{\mathrm{b}}$ & $3.74 \pm 0.27^{\mathrm{c}}$ & $1.01 \pm 0.28^{\mathrm{b}}$ \\
\hline
\end{tabular}

Data expressed as Mean $\pm \mathrm{SE}$

In each row means followed by the same letter are not significantly different $(\mathrm{p}<0.05)$

In each row means followed by different letter are significantly different $(\mathrm{p}<0.05)$

\section{DISCUSSION}

Estimated levls of cadmium in liver, kidney and muscle of examined cattle were $0.52 \pm 0.03,0.58 \pm 0.03$ and $0.40 \pm 0.2 \mathrm{ppm}$ respectively. Analytical findings of cadmium level in liver, kidney and muscles revealed a significant increase in cadmium concentration than acceptable limit $0.05 \mathrm{mg} / \mathrm{kg}$ recommended by David (1993) in muscles. This results were increased the health hazard effect of cadmium. There was an association between cadmium exposure and chronic renal failure [end stage renal disease (ESRD)]. Using a registry of patients, who had been treated for uraemia, the investigators found a double risk of ESRD in persons living close to $(<2 \mathrm{~km})$ industrial cadmium emitting plants as well as in occupationally exposed workers (Hellström et al., 2001). Many literatures have emerged suggesting that also relatively low cadmium exposure may give rise to skeletal damage, evidenced by low bone mineral density (osteoporosis) and fractures (Staessen et al., 1999; Alfven et al., 2000 and Nordberg et al., 2002). A Japanese study showed an excess risk of cardiovascular mortality in cadmium-exposed persons with signs of tubular kidney damage compared to individuals without kidney damage (Nishijo, 1995). The IARC (International Agency for Research on Cancer) has classified cadmium as a human carcinogen 
(group I) on the basis of sufficient evidence in both humans and experimental animals (IARC, 1993). Cadmium has been associated with prostate and kidney cancer (Kolonel, 1976 and Mandel et al., 1995).

In our results, cadmium concentration in kidney is higher than in muscle. Cadmium is a cumulative toxicant in the continental ecological cycling; it accumulates mostly in the liver and kidney (Han et al., 1994). Our obtained results of cadmium level in the liver are nearly similar to levels in the kidney, this result is in harmony with Takayuki and Leonard (1993), who stated that levels of cadmium in kidneys are roughly 10 times the levels in the liver in case of high doses while the levels of cadmium in these two organs become similar with continued low doses.

Cadmium concentration in liver and kidneys of cattle from contaminated areas averaged 0.28 and $1.29 \mathrm{mg} / \mathrm{kg}$ respectively while corresponding values in sheep were 0.29 and $0.547 \mathrm{mg} / \mathrm{kg}$ (Doyle et al., 1993). Antoniou et al. (1995) estimated the cadmium concentration in kidney and liver of goats in contaminated area revealed $3.5 \pm 0.40$ and $0.53 \pm 0.05 \mathrm{mg} / \mathrm{kg}$ respectively while cadmium values in the rural area are $1.3 \pm 0.16 \mathrm{mg} / \mathrm{kg}$ for kidney and $0.19 \pm 0.01 \mathrm{mg} / \mathrm{kg}$ for liver. Doha Ahmed, (2005) estimated the cadmium concentration in cattle liver, kidney and muscles in Assiut governorate and the results were $0.087 \pm$ $0.038,0.152 \pm 0.031$ and $0.008 \pm 0.001$ respectively. Abou-Arab (2001) reported a level of $0.112 \pm 0.07 \mathrm{mg} / \mathrm{kg}$ in cattle liver and $0.320 \pm 0.11$ $\mathrm{mg} / \mathrm{kg}$ in cattle kidney and $0.01 \pm 0.01 \mathrm{mg} / \mathrm{kg}$ in muscle. Our obtained results of cadmium level in liver and kidney were less than the tolerance limits for cadmium which are $1 \mathrm{mg} / \mathrm{kg}$ in liver and $3 \mathrm{mg} / \mathrm{kg}$ in kidney (Spierenburg et al., 1988).

Lead is considered one of the major environmental pollutants and has been incriminated as a cause of accidental poisoning in domestic animals more than any other substance, particularly in cattle, sheep and horses (Liu, 2003). The results of the present study revealed that lead levels in liver, kidney and muscle of examined cattle were $1.20 \pm 0.17$; $3.74 \pm 0.27$ and $1.01 \pm 0.28 \mathrm{ppm}$ respectively was higher than that reported by many authors in different countries. Previous studies reported mean lead levels of $0.440 \pm .0 .07$ and $0.381 \pm 0.03$ in cattle liver and kidney respectively (Abdou et al., 2004). Doha Ahmed, (2005) found that lead concentration in liver, kidney and muscles from male cattle in Assiut governorate were $0.21 \pm 0.03,0.22 \pm 0.01$ and $0.11 \pm$ $0.01 \mathrm{mg} / \mathrm{kg}$ respectively. In addition, Kreuzer et al. (1982) determined 
lead concentrations in liver and kidney of cattle $(\mathrm{mg} / \mathrm{kg} \mathrm{ww})$ as 0.21 and 0.1 respectively.

Tahvonen and Kumpulainen (1994) in Finland found that the average lead content of beef (tenderloin) was $10 \mu \mathrm{g} / \mathrm{kg}$, ground beef 8 $\mu \mathrm{g} / \mathrm{kg}$, cow's liver $37 \mu \mathrm{g} / \mathrm{kg}$. Also López et al. (2000) in Spain found that, the concentrations of lead in slaughtered cattle were, $0.057,0.066$, $0.017 \mathrm{mg} / \mathrm{kg}$ in liver, kidney and muscle respectively. In spite of that, this result was in harmony with our finding, which indicates that lead concentration in kidney tissues is higher than in muscle and liver.

In general, the levels of lead in our estimated samples exceeded the safe permissible limit of lead in meat and meat products which stipulated to be $1.0 \mathrm{mg} / \mathrm{kg}$ by FAO/WHO (1992); $0.5 \mathrm{mg} / \mathrm{kg}$ by Egyptian standards (Egyptian Organization for Standardization and Quality control, 1993); and $1.0 \mathrm{mg} / \mathrm{kg}$ by Codex Alimentarius Commission (FAO/WHO, 2003).

Lead is a well-known neurotoxin. Impairment of neurodevelopment in children is the most critical effect. Exposure in utero, during breast feeding and in early childhood may all be responsible for the effects. Lead accumulates in the skeleton, and its mobilization from bones during pregnancy and lactation causes exposure to fetuses and breastfed infants (WHO, 2007). IARC classified lead as a 'possible human carcinogen' based on sufficient animal data and insufficient human data in 1987. Since then a few studies have been published, the overall evidence for lead as a carcinogen being only weak, the most likely candidates are lung cancer, stomach cancer and gliomas (Steenland and Boffetta, 2000).

Therefore, in view of these results, sufficient effort should be carried out to achieve further reductions in cadmium and lead emissions to the environment as well as roles and methods for food hygiene control measures must applied in order to minimize the risk of adverse health effects.

\section{REFERENCES}

Abdou, Kh.A.; Walaa, A. Moselhy; Ibrahim, Sh. S. and Hassan, H.M. (2004): Estimation of some metallic pollutants in microenvironment of cattle at Beni-Suef governorate. The Sec. Int. Cont. for Develop. and the Envi. In the Arab World, March, 23-25. 
Abou-Arab, A.A. (2001): Heavy metals contents in Egyptian meat and the role of detergent washing on their levels. Food and Chemical Toxicology. 39: 593-599.

Alfven, T.; Elinder, C.G.; Carlsson, M.D.; Grubb, A.; Hellstrom, L. and Persson, B. (2000): Low-level cadmium exposure and osteoporosis. J. Bone Miner. Res. 15: 1579-86.

Antoniou, V.; Zantopoulos, N. and Tsoukali, H. (1995): Selected heavy metal concentrations in goat liver and kidney. Vet. Human Toxicol. 37: 20-32.

Chow, T.J. (1970): Lead accumulation in roadside Soil and grass. Nature 325: 295.

David, W. (1993): Safety of Chemicals in Food. Ellis Horwood Limited. West Sussex. England. pp. 109

Doha, Y. Ahmed (2005): Estimation of some metallic pollutants in hair as an indicative tool to their levels in bovine tissues. Master thesis, Faculty of Veterinary Medicine. Assiut University, Assiut, Egypt.

Doyle, M.E.; Steinhart, C.E. and Cochrane, B.A. (1993): Food Safety. Marcel Dekker, Inc. pp. 321.

Egyptian Organization for Standardization and Quality control, (1993): Maximum Level for Heavy Metal Contamination in Food. ES No. 2360.

FAO/WHO (1992): Codex Alimentarius Commission, Standard Programme Committee on Food Additives and Contaminants, $24^{\text {th }}$ Session Hague, Geneva: WHO.

FAO/WHO (2003): Codex Committee on Food Hygiene, 35th Session, Orlando, Florida, USA, January 27-February 1.

Fleischer, M.; Sarofin, A.M.; Fassett, D.W.; Hammond, P.B.; Schacklette, H.T.; Nisbet, C.T. and Epstein, S. (1974): Environmental impact of cadmium: A review by the panel on hazardous trace substances. Environ. Health Perspect. 7: 253.

Goyer, R.A. (1986): Toxic Effect of Metals. In: J. Doull, C. D. Klassen, and M.O. Amdur (eds), Casarett and Doulls Toxicology: The Basic Science of Poisons, Macmillan, New York. pp. 582

Hammond, P.B. and Aronson, A.L. (1964): Lead poisoning in cattle and horses in the vicinity of a smelter. Ann. New York Acad. Sci. 111: 595.

Han, M.; Enriquez, B.G.; Houpert, P.; Joubert, C. and Milhaud, G. (1994): Pharmacokinetics of cadmium in Ewes; Preliminary study. Vet. Human Toxicol. 36: 185-188. 
Hellström, L.; Elinder, C.G.; Dahlberg, B.; Lundberg, M.; Järup, L.; Persson, B. and Axelson, O. (2001): Cadmium exposure and end-stage renal disease. Am. J. Kidney Dis. 38: 1001-8.

IARC (1993): Cadmium and cadmium compounds. In: Beryllium, Cadmium, Mercury and Exposure in the Glass Manufacturing Industry. IARC Monographs on the Evaluation of Carcinogenic Risks to Humans. International Agency for Research on Cancer 58: 119-237.

Johnson, D.E.; Kienholz, E.W.; Baxter, J.C.; Spangler, E. and Ward, G.M. (1981): Heavy metals retention in tissues of cattle fed high cadmium sewage sludge. J. of animal sci. 52: 108-114.

Koirtyohann, S.R.; Koiser, M.L. and Hinderberger, E.J. (1982): Food analysis for lead using fuxuare Atomic Absorption and Alov Platform. J.O.A.C. 65: 999-1004.

Kolonel, L.N. (1976): Association of cadmium with renal cancer. Cancer; 37: 1782-7.

Kreuzer, W.; Bunzl, K. and Kracke, W. (1982): Lead and cadmium content of liver and kidney of slaughter cattle. Fleischwirtschaft 62: 11.

Lars, J. (2003): Hazards of heavy metal contamination. British Medical Bulletin. 68: 167-182.

Liu, Z.P. (2003): Lead poisoning combined with cadmium in sheep and horses in the vicinity of non-ferrous metal smelters. Science of the Total Environment, 309: 117-126.

López, A.M.; Benedito, J.L.; Miranda, M.; Castillo, C.; Hernández, J. and Shore, R.F. (2000): Toxic and trace elements in liver, kidney and meat from cattle slaughtered in Galicia (NW Spain). Food Addit. Contam. 17: 447-57.

Mandel, J.S.; McLaughlin, J.K.; Schlehofer, B.; Mellemgaard, A.; Helmert, U.; Lindblad, P.; McCredie, M. and Adami, H.O. (1995): International renal-cell cancer study. IV. Occupation. Int. J. Cancer 61: 601-605.

Nishijo, M.; Nakagawa, H.; Morikawa, Y.; Tabata, M.; Senma, M. and Miura, K. (1995): Mortality of inhabitants in an area polluted by cadmium: 15 year follow up. Occup. Environ. Med. 52: 181-184.

Nordberg, G.; Jin, T.; Bernard, A.; Fierens, S.; Buchet, J.P.; Ye, T.; Kong, Q. and Wang, H. (2002): Low bone density and renal dysfunction following environmental cadmium exposure in China. Ambio. 6: 478-481 
Spierenburg, T.J.; DeGraaf, G.J. and Baars, A.J. (1988): Cadmium, Zinc, Lead and Copper in livers and kidneys of cattle in the neighborhood of zinc refineries. Environ. Monitor Assessment 11: 107-114.

Staessen, J.A.; Roels, H.A.; Emelianov, D.; Kuznetsova, T.; Thijs, L. and Vangronsveld, J. (1999): Environmental exposure to cadmium, forearm bone density, and risk of fractures: prospective population study. Public Health and Environmental Exposure to Cadmium (PheeCad) Study Group. Lancet 353: 1140-1144.

Steenland, K. and Boffetta, P. (2000): Lead and cancer in humans: where are we now?. Am. J. Ind. Med.; 38: 295-299.

Swarup, D.; Dwivedi, S.K. and Dey, S. (1997): Lead and cadmium levels in blood and milk of cows from Kanpur City. Indian Journal of animal Sciences 67: 322-323,

Tahvonen, $R$. and Kumpulainen, J. (1994): Lead and cadmium contents in pork, beef and chicken, and in pig and caw liver in Finland during 1991. Food Addit. Contam. 11: 415-426.

Takayuki, S. and Leonard, F.B. (1993): Introduction to Food Toxicology. $1^{\text {st }}$ Ed., Academic Press, Inc. United Kingdom pp.126.

WHO, (2007): Health risks of heavy metals from long-range transboundary air pollution. Joint WHO/Convention Task Force on the Health Aspects of Air Pollution. WHO Regional Office for Europ., Denmark. 